\title{
Baculovirus of Metapenaeus bennettae from the Moreton Bay region of Australia
}

\author{
K. M. Spann, R. J. G. Lester* \\ Department of Parasitology, The University of Queensland, Brisbane, Queensland 4072, Australia
}

\begin{abstract}
Adult Metapenaeus bennettae shrimp, trawled from Moreton Bay, Australia, were found infected with a baculovirus which resembled Monodon Baculovirus (MBV) in its ultrastructure and histological appearance. It differed in that infected material gave negative results with an in situ hybridization test using a DNA probe for MBV, and Penaeus monodon postlarvae, experimentally exposed to the virus, falled to become infected. This new baculovirus, designate MbSNPV or Bennettae Baculovirus (BBV), is the first virus reported from a Metapenaeus spp. taken from the wild.
\end{abstract}

KEY WORDS: Bennettae Baculovirus (BBV) - MbSNPV Morphology DNA probe

\section{INTRODUCTION}

Monodon Baculovirus (MBV) was first described by Lightner \& Redman (1981) in Penaeus monodon shrimp cultured in Taiwan. MBV is now believed to exist as a complex of several related strains. MBV-like baculoviruses have been described for Penaeus merguiensis, $P$. penicillatus, $P$. plebejus, $P$. esculentus, $P$. semisulcatus, $P$. kerathurus and $P$. vannamei and occur in most penaeid culture areas of the IndoPacific (Lightner 1993). In Australia, MBV has been reported in cultured $P$. monodon and wild $P$. merguiensis (Doubrovsky et al, 1988). Plebejus Baculovirus (PBV, Lester et al. 1987), an MBV-like virus, was described from cultured $P$. plebejus. An MBV-like virus has been reported from Metapenaeus ensis, which is cultured in Taiwan (Chen et al. 1989). It is believed that the natural reservoir for $\mathrm{MBV}$ is wild $P$. monodon and other species of susceptible shrimp within the range of the virus (Brock \& Lightner 1990). MBV-like baculoviruses have not been recorded from wild Metapenaeus spp.

MBV causes disease and sometimes mortality of postlarval, juvenile and adult shrimp (Johnson \& Lightner 1988). Not all strains of $\mathrm{MBV}$ cause disease, as

\footnotetext{
·E-mail: r.lester@mailbox.uq.edu.au
}

Bonami observed that Tahitian MBV was not virulent to Penaeus monodon (Natividad \& Lightner 1992) and we have found little mortality in experimentally infected $P$. monodon in Australia (K. M. Spann et al. unpubl.). This study was initiated to assess the infection levels of MBV in wild shrimp near to shrimp farms.

\section{MATERIALS AND METHODS}

Juvenile and adult Metapenaeus bennettae shrimp were collected by beam trawl from 3 inshore sites in Moreton Bay, South-East Queensland, Australia. Two of the sites were adjacent to Penaeus monodon and $P$. japonicus farms. A total of 30 shrimp were sampled on several occasions from each site and the carapace lengths recorded. Prevalence data will be the subject of a separate paper. Smaller samples of $P$. esculentus, P. plebejus and Metapenaeus macleayi were also taken according to availability. Adult and postlarval $P$. monodon and $P$. japonicus shrimp were taken from a farm and hatchery adjacent to one of the sample sites. The cephalothorax of the shrimp was separated from the abdomen and split longitudinally. One longitudinal section was fixed in Davidson's fixative and processed for histology. Sections were stained with haematoxylin and eosin (Humason 1972). Some fresh tissue squashes were stained with $0.05 \%$ aqueous malachite green. 
The remaining portion of hepatopancreas was diced and fixed in $2.5 \%$ gluteraldehyde $/ 2 \%$ paraformaldehyde in cacodylate buffer and postfixed in $1 \%$ osmium tetroxide. The tissue was dehydrated through a graded series of alcohols and mounted in Spurr's resin (Spurr 1969). Sections were cut at $50 \mathrm{~nm}$, stained with uranyl acetate $/ 70 \%$ methanol and Reynold's lead citrate and viewed at $80 \mathrm{kV}$ under a Hitachi $\mathrm{H}-800$ Transmission Electron Microscope (TEM).

From all 3 sites, hepatopancreata of shrimp which contained baculovirus occlusion bodies were tested for MBV using a digoxygenin-labelled DNA probe (Vickers et al. 1993), developed from infected Penaeus monodon postlarvae from South-East Queensland, and an in situ hybridization technique (Rolinghed \& Lindeberg 1992). Histological sections were treated with Proteinase K (Boehringer Mannheim Australia Pty. Ltd., Castle Hill, NSW), the probe cocktail added and allowed to hybridise to the viral DNA present in the section, then the reaction was made visible by use of an antibody-conjugate and colour solution. Sections of $P$. monodon shrimp experimentally infected with local MBV were used as positive controls.

For transmission experiments, infected hepatopancreata collected from all sites were stored at $-70^{\circ} \mathrm{C}$. Penaeus monodon and $P$. japonicus postlarvae, which were $9 \mathrm{~d}$ post-metamorphosis from zoea (PL9), were divided into 5 groups of 500 to 600 shrimp for each species. Shrimp hepatopancreata from each site $(0.5 \mathrm{~g})$ were homogenized on ice with phosphate buffered saline containing $1 \mathrm{mM}$ EDTA, $\mathrm{pH}$ 7. The homogenates were pooled and clarified for $30 \mathrm{~s}$ at $10000 \times \mathrm{g}$, then $1 \mathrm{ml}$ of the supernatant fluid was administered to the water of each of 4 groups of postlarvae. The shrimp were kept in 41 aerated water, which was changed daily, and were fed Artemia nauplii. On Day 5 of the experiment 3 groups were again exposed to the same amount of tissue. On Day 10 only 2 groups were re-exposed and on Day 15 only 1 group. Samples were taken every 3 d. Experiments were carried out in duplicate.

\section{RESULTS}

Wild caught shrimp showed no carapace lesions or other physical signs of disease.

\section{Light microscopy}

Hepatopancreata of most of the Metapenaeus bennettae contained eosinophilic, roughly spherical occlusion bodies (OBs, Fig. 1), which were also clearly seen in fresh smears (Fig. 2). These OBs occurred singly or, more commonly, in clusters of 2 to 8 within the nuclei of proximal epithelial cells, rather than in the generative E-cells. OBs were not detected in any other organs.

\section{Electron microscopy}

Early infections were detected by the presence of marginated or degenerated chromatin and the peripheral migration of the nucleolus (Fig. 3). Infected nuclei were hypertrophied and in advanced infections contained OBs (Fig. 4). The primary change in the cytoplasm of infected cells was an increase in the number of free ribosomes and therefore agranulated endoplasmic reticula (Fig. 5), making the cytoplasm appear very dense. Fibrous material was observed within the nuclei of some infected cells (Fig. 6). The OBs were subspherical, measured up to $9 \mu \mathrm{m}$ in diameter and consisted of regular paracrystalline arrays of subunits (Fig. 7), 15 to $19 \mathrm{~nm}$ in diameter and 24 to $26 \mathrm{~nm}$ from centre to centre. Virogenic stroma were seen within the nuclei of some of the infected cells and occurred as discrete bodies or as zones around the $O B$. Enveloped virions were randomly occluded or free within the nucleus (Fig. 4, arrow). Occasionally the free virions were aligned with each other in such a way as to form loose arrays (Fig. 8). Nucleocapsids measured 238-288 nm $x$ 37-38 nm and fully enveloped virions measured 300-387 $\mathrm{nm} \times 54-56 \mathrm{~nm}$. The envelopes of mature virions formed apical cone-shaped projections at one end and subapical expansions at the other In both longitudinal (Fig, 7) and cross-section a filament can be seen arising from the apex of the nucleocapsid and reflexed within the expanded envelope. Early capsid material and empty capsids were seen in early infections (Fig. 9). OBs and unoccluded virions were observed free in the lumen of the hepatopancreas (Fig. 10).

Figs. 1 10 6. Bennettae Baculovirus (BBV) in hepatopancreatic epithelial cells of Metapenaeus bennettae. Fig. 1. Multiple occlusion bodies (arrows) within nuclei. L: lumen of hepatopancreatic tubule. H\&E stain. Scale bar $=5 \mu \mathrm{m}$. Fig. 2 . Fresh tissue squash showing occlusion bodies (arrows). $0.05 \%$ aqueous malachite green stain. Scale bar $=5 \mu \mathrm{m}$. Fig. 3 . TEM of an early infection showing hypertrophied nucleus (HN), marginated nucleolus ( $N$ ), degenerative chromatin (C) and scattered unoccluded virions (arrows). Scale bar $=300 \mathrm{~nm}$. Fig. 4. Advanced infection with hypertrophied nucleus (N) containing 2 occlusion bodies (OB) and free virions (arrow). Scale bar $=200 \mathrm{~nm}$. Fig. 5. Free ribosomes (arrow) and agranulated (A) endoplasmic reticula within the cytoplasm of an infected hepatopancreocyte. The neighbouring uninfected cell has normal rough endoplasmic reticula ( $E R$ ). Scale bar $=400 \mathrm{~nm}$. Fig. 6. Fibrous material (F) within the nucleus. Scale bar $=300 \mathrm{~nm}$ 

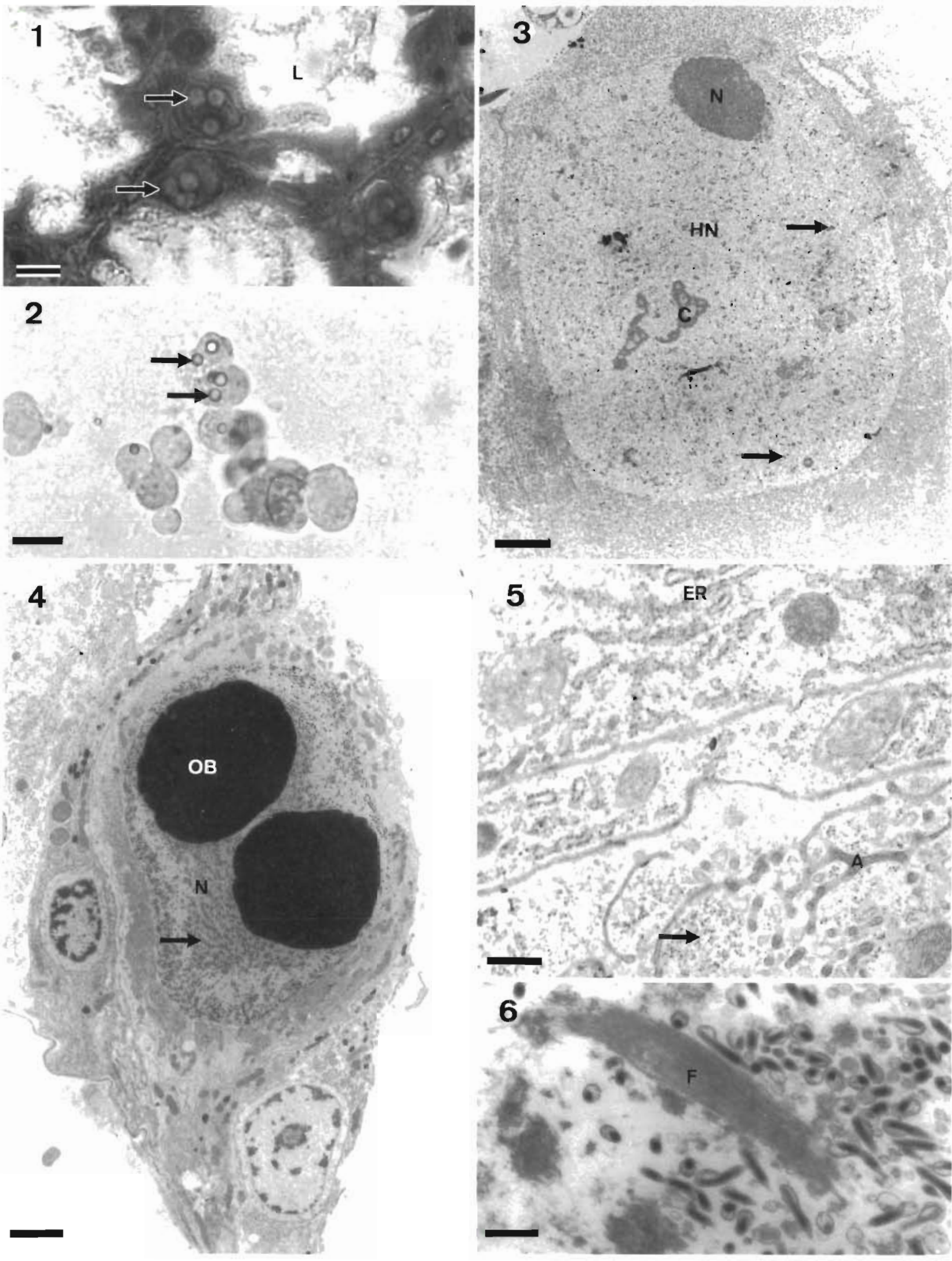

5 ER

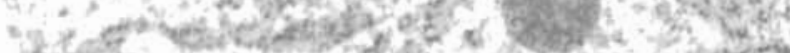

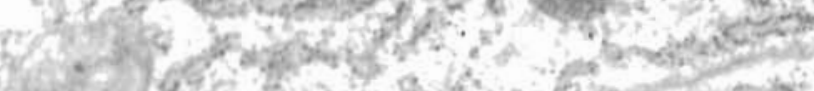

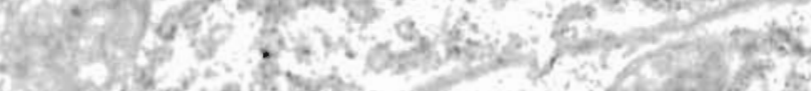

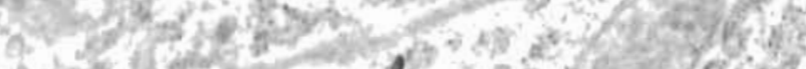
be

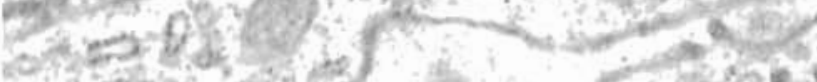

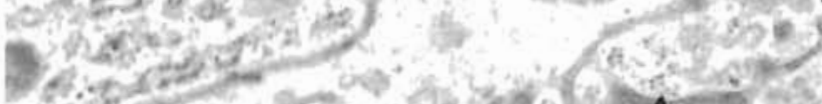

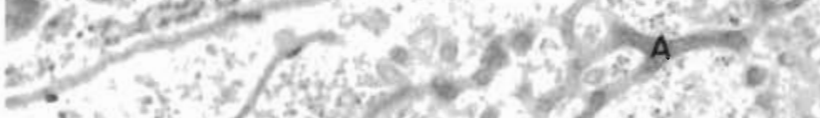

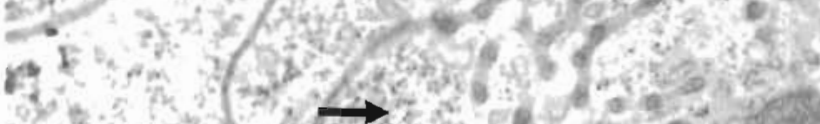

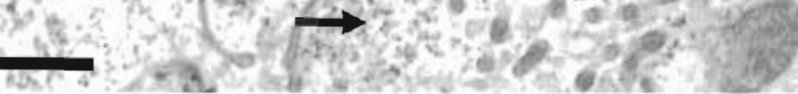

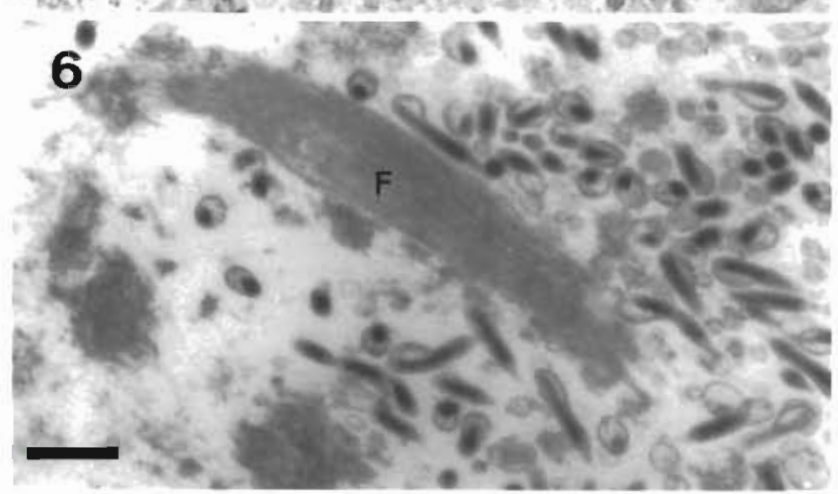




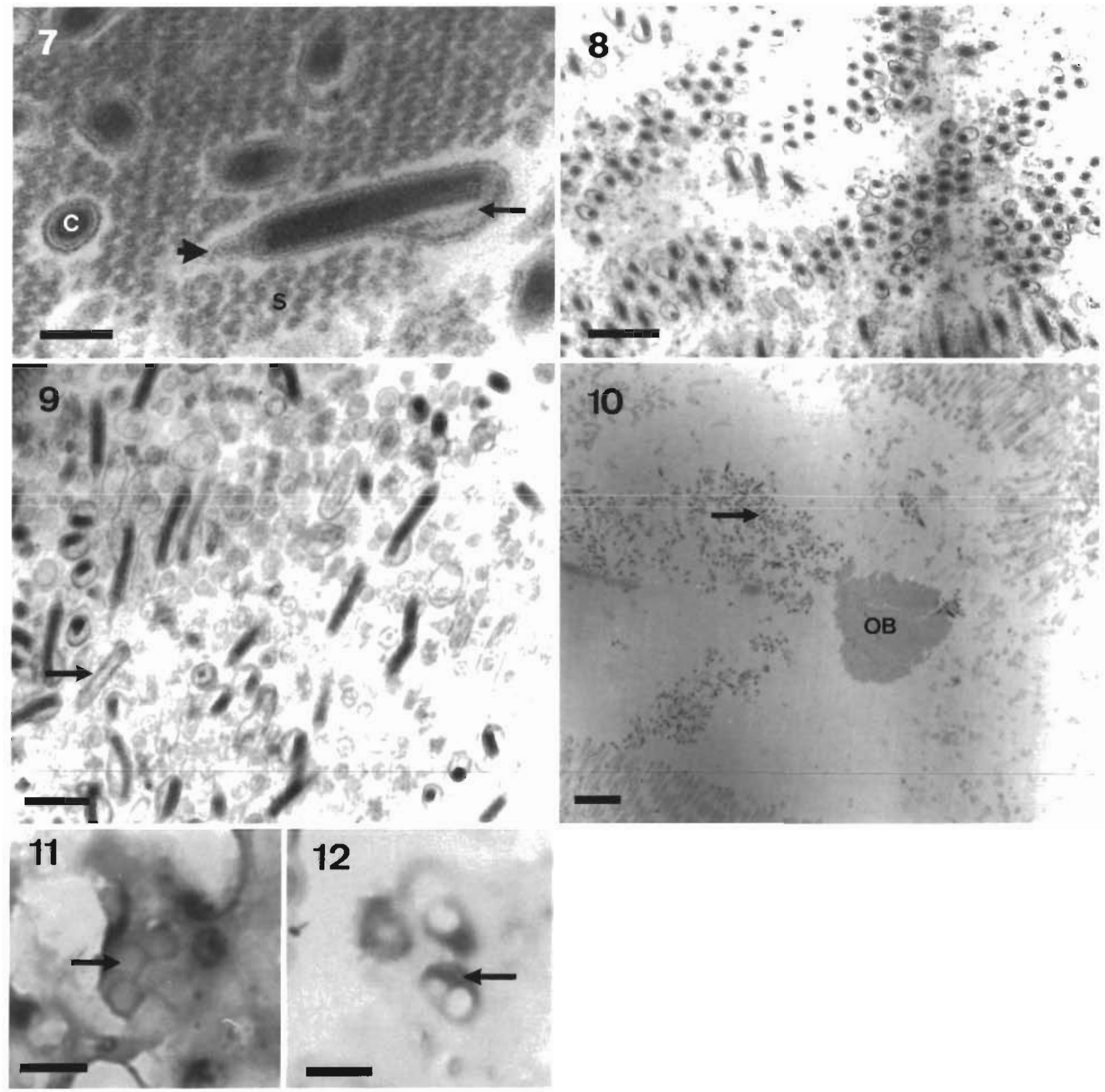

Figs. 7 to 12. Hepatopancreatic cells of Metapenaeus bennettae infected with Bennettae Baculovirus (BBV). Fig. 7 . Occluded enveloped virions. In longitudinal section, an apical cone-shaped projection (arrow head) and filament (arrow) reflexed within an envelope expansion can be seen. The structure of the virions as seen in cross section (C) is typical of baculoviruses. s: occlusion body subunits. Scale bar $=80 \mathrm{~nm}$. Fig. 8 . Regular arrays of free, enveloped virions within an infected nucleus. Scale bar $=300 \mathrm{~nm}$. Fig. 9. Early infection with empty capsids (arrow) and abundant capsid material. Scale bar $=200 \mathrm{~nm}$. Fig. 10. Occlusion body (OB) and virions (arrow) free within the Iumen of the hepatopancreas. Scale bar $=1 \mu \mathrm{m}$. Fig. 11. Hepatopancreas of $M$. bennettae after hybridisation with the probe. Negative result. Arrow: occlusion boriv: Scale bar $=3 \mu \mathrm{m}$. Fig. 12. Hepatopancreas of $P$. monodon after

hybridisation with a probe for Monodon Baculovirus (MBV). Arrow indicates the presence of MBV DNA. Scale bar $=4 \mu \mathrm{m}$

\section{Other observations}

Sections of infected hepatopancreata of Metapenaeus bennettae gave negative results when tested with an MBV-specific DNA probe (Fig. 11) whereas the control section from Penaeus monodon gave a strong positive re- sult (Fig. 12). Postlarvae of $P$. monodon and P. japonicus did not develop $O B$ s when exposed to the virus in either trial. Infection levels of Bennettae Baculovirus (BBV or MbSNPV) in $M$. bennettae from the 3 sampling sites were not significantly different. No OBs were observed in the P. esculentus, P. plebejus and M. macleayi sampled. 


\section{DISCUSSION}

The presence of rod-shaped virions occluded within eosinophilic, proteinaceous bodies in nuclei of Metapenaeus bennettae sampled from Moreton Bay indicates that the shrimp were infected with a nuclear polyhedrosis baculovirus. This baculovirus, which we designate $B B V$ or MbSNPV, resembles $M B V$ in its morphology.

Early BBV infections can be identified by the breakdown of chromatin, the peripheral migration of the nucleolus and hypertrophied nuclei similar to early infections of MBV, Baculovirus penaei (BP) and Baculoviral midgut-gland necrosis virus (BMNV) (Sano et al. 1981, Johnson \& Lightner 1988, Brock \& Lightner 1990). BBV and MBV infections are histologically diagnosed by the presence of eosinophilic OBs within the nuclei of hepatopancreocytes other than developmental E-cells (Brock \& Lightner 1990). BBV OBs, like those of $\mathrm{MBV}$, occur primarily in multiples rather than singly (Brock \& Lightner 1990). They are both subspherical rather than polyhedral, which is the more characteristic shape of baculovirus OBs (Federici 1986), and the polyhedrin subunits of the crystalline lattice are of similar size and periodicity (Brock \& Lightner 1990)

MBV nucleocapsids, as described from Australian Penaeus monodon and $P$. merguiensis, average $45-52 \mathrm{~nm}$ $\times 260-300 \mathrm{~nm}$ (Doubrovsky et al. 1988). These measurements are slightly larger but overlap those for MBV from the IndoPacific, where nucleocapsids measure $42 \pm 3 \mathrm{~nm} \times 246 \pm 15 \mathrm{~nm}$, and the enveloped virions measure $75 \pm 4 \mathrm{~nm} \times 324 \pm 33 \mathrm{~nm}$ (Lightner et al. 1983). The nucleocapsids of BBV (238-288 $\mathrm{nm} \times$ 37-38 nm) are about the same length but are much narrower than nucleocapsids of MBV. Similarly, enveloped virions of $B B V$ are of a similar length to those of MBV but are not as wide.

The structure of the virions, as seen in cross-section, is typical of baculoviruses, having a nucleoprotein core, capsid and trilaminar envelope (Federici 1986). Enveloped virions of BBV have envelope expansions, supported by a reflexed filament, and cone-shaped projections like those described for MBV (Johnson \& Lightner 1988). Unilateral envelope expansions are also a feature of BP (Couch 1974) and Baculo-PP of the crab Paralithodes platypus (see Johnson \& Lightner 1988). The organization of enveloped virions into orderly arrays within the nucleoplasm is atypical of MBV (Lightner et al. 1983)

The cytoplasmic changes reported for BBV are less extensive than for MBV or BP. Abnormal mitochondria and golgi apparatus and membranous labyrinths (Chen et al. 1989, Couch 1989, Brock \& Lightner 1990) were not seen in this BBV-infected material. However, fibrous material in the nucleus (Brock \& Lightner 1990) and an increase in the number of free ribosomes (Lightner et al. 1983, Couch 1989) have been reported for $M B V$ and $B P$

There was no difference between BBV infection levels for the 3 sites. Hence there was no correlation. between prevalence and proximity to shrimp culture facilities. BBV appears to be specific to Metapenaeus bennettae as other species sampled were not infected. We experimentally exposed PL-9 postlarvae of Penaeus monodon and $P$. japonicus to water-borne homogenates of infected tissue, a method used routinely by us and others (Natividad \& Lightner 1992, Paynter et al. 1992) for infecting shrimp with MBV. Re-exposure of the postlarvae to $\mathrm{BBV}$ homogenates further increased the chance of infection. The results indicate that $P$. monodon and $P$. japonicus are refractory to this virus.

The DNA probe, which was used against BBV, has given positive results for $M B V$-infected tissue from South-East Queensland, North Queensland and Thailand (J. E. Vickers pers. comm.), indicating that it is not specific to one strain of $\mathrm{MBV}$. The protein matrix of the $\mathrm{OB}$ of $\mathrm{BBV}$ could have presented an obstacle to the probe (Poulos et al. 1994). However TEM showed that most BBV virions were unoccluded and therefore were available to react with the probe. The negative result for $\mathrm{BBV}$-infected tissue reinforces the conclusion that this virus is distinct from $\mathrm{MBV}$

Acknowledgements. We thank Ms Jenny Wang, Department of Microbiology, for help with the in situ hybridisation and Mr Eric Boel, Department of Parasitology, for assistance with collecting samples. This study was supported by a grant from the CRC for Aquaculture (to R.J.C.L.) and an Australian Postgraduate Award (to K.M.S.)

\section{LITERATURE CITED}

Brock JA, Lightner DV (1990) Diseases of Crustacea. In: Kinne $O$ (ed) Diseases of marine animals, Vol 3. Biologische Anstalt Helgoland. Hamburg, p 245-423

Chen SN, Lo CF, Liu SM, Kou GH (1.989) The first identification of Penaeus monodon Baculovirus (MBV) in the cultured sand shrimp Metapenaeus ensis. Bull Eur Ass Fish Pathol 9(3):62-64

Couch JA (1974) An enzootic nuclear polyhedrosis virus of pink shrimp: ultrastructure, prevalence and enhancement J Invertebr Pathol 24:311-331

Couch JA (1989) The membranous labyrinths in baculovirusinfected crustacean cells: possible roles in viral reproduction. Dis Aquat Org 7:39-53

Doubrovsky A, Paynter JL, Sambhi SK, Atherton JG, Lester RJG (1988) Observations on the ultrastructure of baculovirus in Australian Penaeus monodon and Penaeus merguiensis. Aust J Mar Freshwater Res 39:743-749

Federici BA (1986) Ultrastructure of baculoviruses. In: Granados RR, Federici BA (eds) The biology of baculoviruses, Vol 1. Chap 3, CRC Press, Boca Raton, p 61-88 
Humason GL (1972) Animal tissue techniques. WH Freeman and Co, San Francisco

Johnson PT, Lightner DV (1988) Rod-shaped nuclear viruses of crustaceans: gut-infecting species. Dis Aquat Org 5 $123-1410$

Lester RJG, Doubrovsky A, Paynter JL, Sambhi SK, Atherton JG (1987) Light and electron microscopical evidence of a baculovirus infection in the prawn Penaeus plebejus. Dis Aquat Org 3:217-219

Lightner DV (1993) Diseases of cultured penaeid shrimp. In: MCVey JP (ed) CRC handbook of mariculture, Vol 1, Crustacean aquaculture. CRC Press, Boca Raton, p 393-486

Lightner DV, Redman RM (1981) A baculovirus-caused disease of the penaeid shrimp, Penaeus monodon. J Invertebr Pathol 38:299-302

Lightner DV, Redmand RM, Bell TA (1983) Observation on the geographic distribution, pathogenesis and morphology of the baculovirus from Penaeus monodon Fabricius. Aquaculture 32:209-233

Natividad JM, Lightner DV (1992) Susceptibility of the different larval and postlarval stages of the black tiger prawn, Penaeus monodon, Fabricius, to monodon baculovirus (MBV). In. Shariff M. Subasinghe RP, Auther JR (eds) Disease in Asian aquaculture. Fish Health Section, Asian Fisheries Society, Manila, p 111-1.25

Responsible Subject Editor: J. E. Stewart, Dartmouth, Nova Scotia, Canada
Paynter JL, Vickers JE, Lester RJG (1992) Experimental transmission of $P$. monodon-type baculovirus (MBV). In: Shariff M, Subasinghe RP, Auther JR (eds) Diseases in Asian aquaculture. Fish Health Section, Asian Fisheries Society, Manila, p $97-110$

Poulos BA, Mari J, Bonami JR, Redman R, Lightner DV (1994) Use of non-radioactive labeled DNA probes for the detection of baculovirus from $P$. monodon by in situ hybridization on fixed tissue. J Virol Methods 49:187-194

Rolinghed J, Lindeberg H (1992) Detection of HPV 11 DNA in paraffin-embedded laryngeal tissue with a DIG-labeled DNA probe. In: Non-radioactive in-situ hybridization application manual. Boehring-Mannheim, Biochemica, Mannheim, p 48-50

Sano $T$, Nishimura $T$, Oguma $K$, Momoyama $K$, Takeno N (1981) Baculovirus infection of cultured kuruma shrimp, Penaeus japonicus in Japan. Fish Pathol 15:185-191

Spurr AR (1969) A low viscosity epoxy resin embedding medium for electron microscopy. J Ultrastruct Res 26:31-43

Vickers JE, Bonami JR, Flegel TW, Ingham AB, Kidd SP, Lester RJG, Lightner DV, Mari J, Pemberton JM, Spradbrow PB, Wang JH, Wong FYK, Young PR (1993) A gene probe for monodon bacuiovirus. In: Fish Hectith Section, Asian Fisheries Society. 2nd Symp Dis Asian Aquacult. Asian Fish Soc, Phuket, p 2 (Abstract)

Manuscript first received: October 23, 1995

Revised version accepted: April 15, 1996 